\title{
SYNTHESIS AND DOCKING STUDIES OF 1-(2- FLUOROPHENYL)-3-(4-((PYRIDINE-2-YL) METHYL) PIPERAZINE-1-YL)-1 $H$-INDAZOLE
}

\author{
V. Balaraju ${ }^{1,2}$, S. Kalyani ${ }^{1}$ andE. Laxminarayana, ${ }^{2, *}$ \\ ${ }^{1}$ Mahatma Gandhi University, Anneparthy, Nalgonda- 508254 (Telangana) India \\ ${ }^{2}$ Sreenidhi Institute of Science and Technology (Autonomous), Ghatkesar, \\ Hyderabad-501 301 (Telangana) India. \\ *E-mail: elxnkits@yahoo.co.in
}

\begin{abstract}
Piperazine-1-yl-1H-indazole derivatives play a very important role in the field of medicinal chemistry. Novel compound 1-(2-fluorophenyl)-3-(4-((pyridine-2-yl) methyl) piperazin-1-yl)-1H-indazole is synthesized in a simple and efficient process. All the compounds are characterized by spectral analysis. Further, docking studies for this titled compound are also presented in this communication.
\end{abstract}

Keywords: 2-Bromo-N-(2-fluorophenyl) benzohydrazide, 2-(Bromomethyl) pyridine Hydrobromide, antibacterial activity

() RASĀYAN. All rights reserved

\section{INTRODUCTION}

Indazoles are heterocyclic aromatic organic compounds, also called isoindazoles. This bicycle compound consists of the fusion of benzene and pyrazole. Indazoles are rare in nature. The alkaloids nigellicine, nigeglanine, and nigellidine are indazoles. Nigellicine was isolated from the widely distributed plant Nigella sativa L. (black cumin). Nigeglanine was isolated from extracts of Nigella glandulifera.<smiles>Cc1cc(O)c2c(C(=O)[O-])[n+]3n(c2c1)CCCC3</smiles>

Nigellicine<smiles>Cc1cc2n3n(cc-2c(=O)c1)CCCC3</smiles>

Nigeglanine<smiles></smiles>

Nigellidine

Fig.-1

Indazoles derivatives display a wide-ranging variety of biological activities. Mainly because of their occurrence in drugs, there has been a sustained interest, in the past few years, for the discovery of new and efficient methods to prepare variously substituted $1 H$ - and $2 H$-indazoles.

The indazole nucleus is a pharmaceutically important structure that constitutes the key subunit in many drugs with a broad range of pharmacological activities. The 1,3,5-substituted indazoles have been studied as receptor antagonists of the peptideo-leukotrienes. ${ }^{1}$ Most of the derivatives of Indazole are recognized to have effective pharmacological activity, for instance, anti-inflammatory, anti-tumor or HIV protease inhibition, ${ }^{2,3}$ and inhibition of protein kinase C-B/AKt inhibitors ${ }^{4}$ In actual fact, compounds with Indazoleframe are notorious for their variety of biological activities such as high binding affinity for estrogen receptor, ${ }^{5}$ antifungal and antibacterial activity. ${ }^{6}$

Rasayan J. Chem., 12(2), 677-684(2019)

http://dx.doi.org/10.31788/RJC.2019.1225111

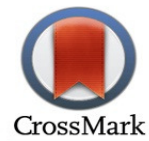




\section{RASĀYAN J. Chem.}

Human neutrophil elastase (HNE) plays an important role in tumor invasion and inflammation. A series of N-benzoylindazoles was synthesized and evaluated for their ability to inhibit HNE. ${ }^{7}$ By incorporating aryl groups on 5-positions and monomethyl amide function at 2-positions may lead to the synthesis of more significant AKT inhibitors than the existing. ${ }^{8}$ A new series of 1H-pyridine-4-yl-indazole-3carboxylic acid and its derivatives were synthesized from indazole-3-carboxylic acid methyl ester and 2cyano-4-chloropyridine. All the new compounds have been characterized by spectral data and subsequently evaluated for their anti-inflammatory and analgesic activity. ${ }^{9} N$-methyl and $N$-ethyl substitutedindazoles reported are tested to evaluate their antimicrobial, antiproliferative and COX inhibitory activities, showing limited to moderate antiproliferative activity and some inhibitory activity

against COX-1 and COX-2. ${ }^{10,11}$ A series of hydrazide-hydrazones linked indole and indazole moieties were designed and synthesized. Prepared a set of $2 \mathrm{H}$-indazole derivative compounds commonly have antimicrobial and anti-inflammatory activity ${ }^{12}$. The derivatives were synthesized and presented docking studies. The regioselective synthesis of $N$-alkylated indazoles in Citric acid-mediated green synthetic route has been established for good to excellent yields from readily available starting materials 2-methyl anilines, $\mathrm{NaNO}_{2}$ and ethyl chloroacetate via diazotization, intramolecular cyclization and followed by $N$ alkylation in the presence of 1:1 ratio of ethanol and water in one-pot. ${ }^{13}$

\section{CHEMISTRY}

\section{RESULTS AND DISCUSSION}

The synthesis of the target compound was accomplished according to multistep reactions in a sequence as outlined in the scheme.

A solution of 2-Bromo- $N$-(2-fluorophenyl) benzohydrazide(1) and triphenylphosphine was added to carbon tetrachloride in dry acetonitrile at room temperature and stirred for $2 \mathrm{~h}$ to get (Z)-1-((2bromophenyl)chloromethylene)-2-(2-fluorophenyl)hydrazine(2).Compound-2 was added to an ice-cold solution of tert-butyl piperazine-1-carboxylate (3) and triethylamine in anhydrous THF and stirred at room temperature for $12 \mathrm{~h}$ to get compound-4. A mixture of compound-4, Copper iodide and potassium carbonate in NMP was stirred at $130{ }^{\circ} \mathrm{C}$ for $3 \mathrm{~h}$ to afford tert-butyl 4-(1-(2-fluorophenyl)- $1 \mathrm{H}$-indazol-3yl)piperazine-1-carboxylate (5). A solution of compound-5 in methanol was added to $4 \mathrm{M} \mathrm{HCl}$ in 1,4Dioxane at $0{ }^{\circ} \mathrm{C}$ and stirred at room temperature for $10 \mathrm{~h}$ to afford 1-(2-fluorophenyl)-3-(piperazin-1-yl)1H-indazole (6). 2-(Bromomethyl)pyridine Hydrobromide was added to a suspension of compound-6 and potassium carbonate in DMF at $0{ }^{\circ} \mathrm{C}$ and stirred at room temperature for $12 \mathrm{~h}$ to get target product 1-(2fluorophenyl)-3-(4-((pyridine-2-yl)methyl)piperazin-1-yl)-1 $H$-indazole.

Compound-1 was synthesized by following standard procedures and characterized by comparing with authentic values. ${ }^{14}$ The synthesized compound was analysed in silico using the docking server software. ${ }^{15}$ In continuous to the earlier work ${ }^{16,17}$ we herein report synthesis and docking studies of title compounds

\section{Docking Studies}

The molecule which was docked was 5Cox, a ccylogensae enzyme which plays a major role in inflammation. The compound should good anti-inflammatory activity as the estimated free energy of binding was found to be $-5.23 \mathrm{kcal} / \mathrm{mol}$ (Table-1) which indicates a better interaction and stronger binding with the enzyme. The amino acids glutamic acid, tyrosine and glutamine were shown to be in close vicinity of the interaction (Table-2). Table-3 shows all the interactions involving bonds through which amino acids of the enzyme made close binding with the ligand. The Fig.-2 shows the docking pose of the ligand and the enzyme along with the proximity of some of the amino acids especially glutamic acid and tyrosine with the ligand.

\section{EXPERIMENTAL}

Chemical and solvents used were purchased either from Fluka or Merck. All the reagents were of analytical grade. Thin-layer chromatography (TLC) was performed on E. Merck AL silica gel 60 F254 plates and visualized under UV light. ${ }^{1} \mathrm{H}$ NMR spectra were recorded in DMSO- $d_{6}$ by a Varian Mercury plus $400 \mathrm{MHz}$ instruments, respectively. Signals caused by residual protonated solvent $\left({ }^{1} \mathrm{H} \mathrm{NMR}\right)$ served as the internal standard. All the chemical Shifts were reported in $\delta(\mathrm{ppm})$ using tetramethylsilane as an internal standard. The ${ }^{1} \mathrm{H}$ NMR chemical shifts and coupling constants were determined to assume first- 
order behavior. Multiplicity is indicated by one or more of the following: s (singlet), $\mathrm{d}$ (doublet), $\mathrm{t}$ (triplet), q (quartet), m (multiplet), and br (broad). Mass spectra were recorded with a PE Sciex model API 3000 instrument. All the reactions were carried out under argon atmosphere.
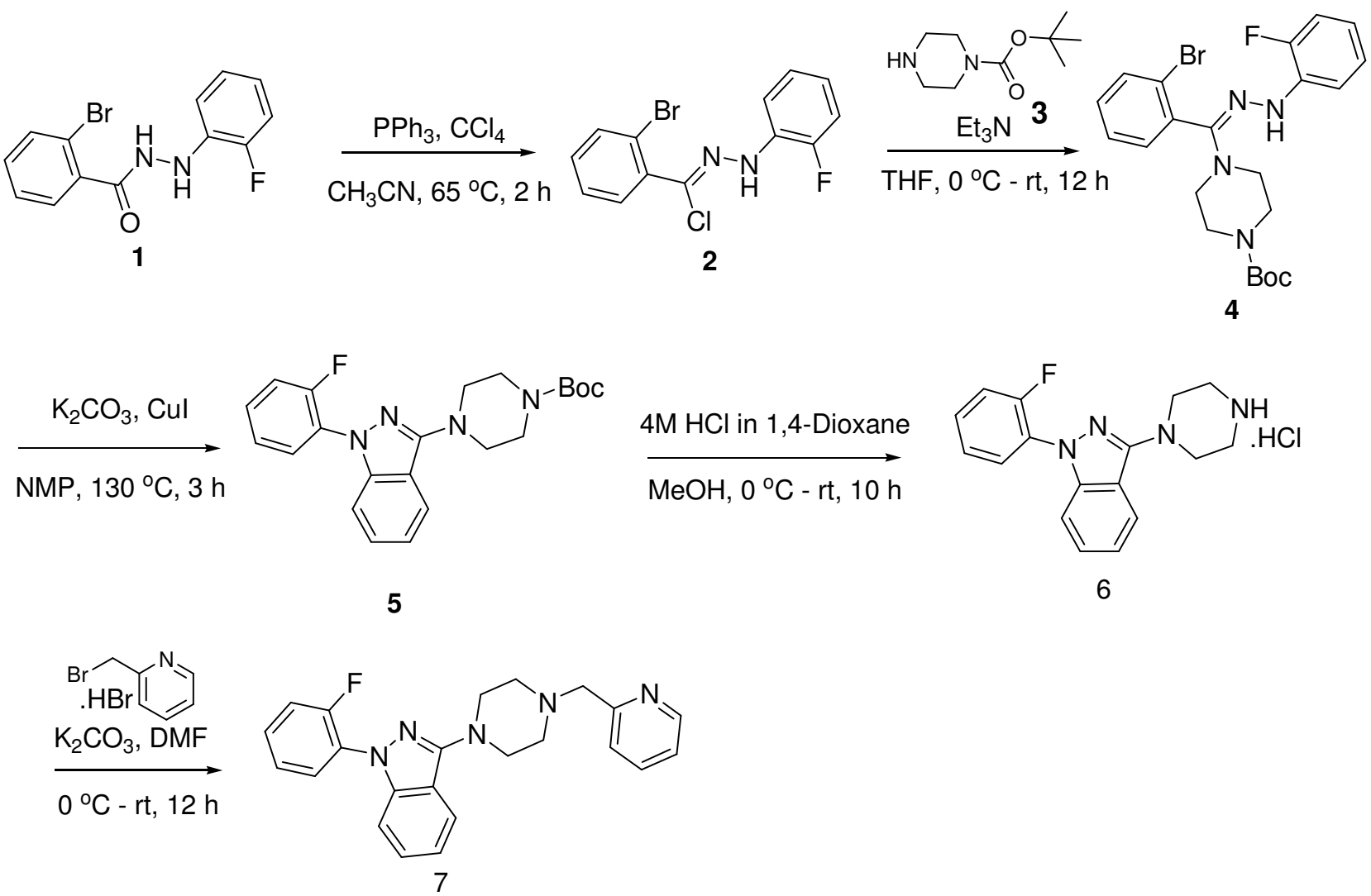

Scheme-1

Synthesis of1-((2-bromophenyl) chloromethylene)-2-(2-fluorophenyl) hydrazine (2)

Carbon tetrachloride $(30 \mathrm{ml})$ was added to a solution of 2-Bromo- $N$ '-(2-fluorophenyl) benzohydrazide (1) $(0.1 \mathrm{~mole})$ and Triphenylphosphine $(0.1 \mathrm{~mole})$ in dry acetonitrile at $65^{\circ} \mathrm{C}$ and stirred for $2 \mathrm{~h}$. The reaction progress was monitored by TLC (TLC silica gel plate), 10\% ethyl acetate in Pet ether, using $254 \mathrm{~nm}$ UV light to visualize the spot. After completion of the reaction the reaction mixture was concentrated in reduced pressure to get $0.93 \mathrm{~g}$ of crude product. The crude product was absorbed on $300 \mathrm{~g}$ of silica gel (100-200 mesh) and loaded over a pre-packed column with silica gel [80 $\mathrm{mm} \times 100 \mathrm{~cm}$ width and height of column; $800 \mathrm{~g}$ of 100-200 silica gel. Elution started with $2 \%$ ethyl acetate in pet ether and finished with $10 \%$ ethyl acetate in pet ether. All pure fractions were collected and concentrated under reduced pressure to afford compound-2 (68\%).

${ }^{1} \mathrm{H}$ NMR (300 MHz, DMSO-d $)$ ) 9.0 (s, 1H), 7.91-7.76 (d, 1H), 7.68-7.65 (d, 1H), 7.54-7.49 (t, 1H), 7.46$7.39(\mathrm{~m}, 2 \mathrm{H}), 7.27-7.20(\mathrm{t}, 1 \mathrm{H}), 7.15-7.10(\mathrm{t}, 1 \mathrm{H}), 6.99-6.93(\mathrm{~m}, 1 \mathrm{H})$. HPLC: $97.19 \%$ at $215 \mathrm{~nm}, 98.35 \%$ at $254 \mathrm{~nm}$.

Synthesis of 1-((2-bromophenyl) tert-butylpiperazinyl)-2-(2-fluorophenyl) hydrazine (4)

Tert-butyl piperazine-1-carboxylate (3) (0.01 mole) added to an ice-cold solution of 1-((2-bromophenyl) chloromethylene)-2-(2-fluorophenyl) hydrazine (2) (0.015 mole) and triethylamine (0.015 mole) in anhydrous THF (30ml) and stirred at room temperature for $12 \mathrm{~h}$. The progress of the reaction was monitored by TLC [(TLC silica gel plate), $30 \%$ Ethyl acetate in pet ether, using $254 \mathrm{~nm}$ UV light to visualize the spot]. Subsequent to completion of the reaction, the reaction mixture filtered and the filtrate was concentrated under reduced pressure to get the crude product. In the next step, this crude product was directly used without any additional purification. 
Synthesis of tert-butyl 4-(1-(2-fluorophenyl)-1H-indazol-3-yl) piperazine-1-carboxylate (5)

A mixture of 1-((2-bromophenyl) tert-butylpiperazinyl)-2-(2-fluorophenyl) hydrazine (4) (0.01 mole), Copper iodide $(0.01 \mathrm{~mole})$ and potassium carbonate $(0.01 \mathrm{~mole})$ in NMP $(20 \mathrm{ml})$ was stirred at $130{ }^{\circ} \mathrm{C}$ for $3 \mathrm{~h}$. The reaction was monitored by TLC [(TLC silica gel plate), $30 \%$ Ethyl acetate in pet ether using 254 $\mathrm{nm}$ UV light to visualize the spot]. After completion of the reaction, the reaction mixture was poured in ice water and extracted from Ethyl acetate $(3 \times 300 \mathrm{~mL})$. The combined organic layers were washed with water, brine and concentrated under reduced pressure to afford $40 \mathrm{~g}$ of crude product. The crude product was absorbed on $80 \mathrm{~g}$ of silica gel (60-120 mesh) and loaded over a pre-packed column with silica gel [60 $\mathrm{mm} \times 80 \mathrm{~cm}$ width and height of column; $300 \mathrm{~g}$ of 60-120 silica gel]. Elution started with $20 \%$ ethyl acetate in pet ether and finished with $30 \%$ ethyl acetate in pet ether. All pure fractions were collected and concentrated under reduced pressure to afford compound-5 (73\% from 2 steps).

${ }^{1} \mathrm{H}$ NMR $\left(300 \mathrm{MHz}, \mathrm{CDCl}_{3}\right):$ 7.76-7.73 $(\mathrm{d}, 1 \mathrm{H}), 7.6-7.55(\mathrm{t}, 1 \mathrm{H}), 7.40-7.24(\mathrm{~m}, 5 \mathrm{H}), 7.16-7.11(\mathrm{t}, 1 \mathrm{H})$, 3.68-3.65 (t, 4H), 3.49-3.46 (t, 4H), $1.49(\mathrm{~s}, 9 \mathrm{H})$. LCMS: 93.27\% (m/z = 397.1 (M+H) $\left.)^{+}\right)$

\section{Synthesis of 1-(2-fluorophenyl)-3-(piperazin-1-yl)-1H-indazole (6)}

$4 \mathrm{M} \mathrm{HCl}$ in 1,4-Dioxane added to a solution of compound-5 in methanol at $0{ }^{\circ} \mathrm{C}$ and stirred at room temperature for $10 \mathrm{~h}$. The reaction was monitored by TLC (TLC silica gel plate), $10 \%$ methanol in DCM using $254 \mathrm{~nm}$ UV light to visualize the spot]. After completion of the reaction, the reaction mixture was concentrated under reduced pressure afford crude product. The crude product was triturated with diethyl ether and filtered to afford the product $(67 \%)$.

${ }^{1} \mathrm{H}$ NMR (400 MHz, DMSO-d ${ }_{6}$ ): 9.35 (brs, 2H), 7.98-7.96 (d, $\left.J=8.4 \mathrm{~Hz}, 1 \mathrm{H}\right), 7.66-7.62$ (t, $J=7.8 \mathrm{~Hz}$, $1 \mathrm{H}), 7.52-7.37(\mathrm{~m}, 4 \mathrm{H}), 7.30-7.27(\mathrm{~m}, 1 \mathrm{H}), 7.21-7.17(\mathrm{t}, J=7.6 \mathrm{~Hz}, 1 \mathrm{H}), 3.66$ (brs, 4H), 3.31 (brs, 4H). HPLC: $98.10 \%(215 \mathrm{~nm}), 98.18 \%(254 \mathrm{~nm})$, Mass: $\left(\mathrm{m} / \mathrm{z}=297.0[(\mathrm{M}-\mathrm{HCl})+\mathrm{H}]^{+}\right.$.

\section{Synthesis of 1-(2-fluorophenyl)-3-(4-((pyridine-2-yl) methyl) piperazin-1-yl)-1H-indazole (7)}

2-(Bromomethyl) pyridine Hydrobromide (0.01 mole) was added to a suspension of 1-(2-fluorophenyl)-3(piperazin-1-yl)-1H-indazole (6) (0.01 mole) and potassium carbonate in DMF at $0{ }^{\circ} \mathrm{C}$ and stirred at $\mathrm{rt}$ for $12 \mathrm{~h}$. The reaction was monitored by TLC [(TLC silica gel plate), Ethyl acetate using $254 \mathrm{~nm}$ UV light to visualize the spot]. After completion of the reaction, the reaction mixture was poured in ice water and extracted with Ethyl acetate $(3 \times 100 \mathrm{~mL})$. The combined organic layers were washed with water, brine and concentrated under reduced pressure to afford crude product. The crude product was purified by flash chromatography Elution started with 30\% Ethyl acetate in pet ether and finished with $60 \%$ Ethyl acetate in pet ether. All pure fractions were collected and concentrated to give the product (62\%).

${ }^{1} \mathrm{H}$ NMR $\left(300 \mathrm{MHz}, \mathrm{DMSO}_{-} \mathrm{d}_{6}\right)$ : 8.53-8.51 $(\mathrm{d}, 1 \mathrm{H}), 7.92-7.89(\mathrm{~d}, 1 \mathrm{H}), 7.81-7.78(\mathrm{t}, 1 \mathrm{H}), 7.64-7.59(\mathrm{t}$, $1 \mathrm{H}), 7.51-7.34(\mathrm{~m}, 5 \mathrm{H}), 7.30-7.22(\mathrm{~m}, 2 \mathrm{H}), 7.16-7.11(\mathrm{t}, 1 \mathrm{H}), 3.7(\mathrm{~s}, 2 \mathrm{H}), 3.46$ (brs, 4H), 2.67 (brs, 4H).HPLC: $97.43 \%(215 \mathrm{~nm}), 98.88 \%(254 \mathrm{~nm})$. Mass: $\left(\mathrm{m} / \mathrm{z}=388.0[\mathrm{M}+\mathrm{H}]^{+}\right)$.

\section{CONCLUSION}

In conclusion, we have developed a simple, effective, stable and inexpensive methodology to prepare title compound. The compound has given significant docking results. The structures of all the new products obtained in the present work are supported by spectral and analytical data.

\section{ACKNOWLEDGMENT}

The authors are thankful to Management, Executive Director, and Head, Department of Science \& Humanities of SNIST Hyderabad, Vice-Chancellor and Registrar of Mahatma Gandhi University, Nalgonda for providing research facilities, grants and for their encouragement.

Table-1: Compound to $1 \mathrm{jff}-$ Structural Protein

\begin{tabular}{c|c|c|c|c|c|c}
\hline $\begin{array}{c}\text { Est. Free Energy } \\
\text { of Binding }\end{array}$ & $\begin{array}{c}\text { Est. Inhibition } \\
\text { Constant, Ki }\end{array}$ & $\begin{array}{c}\text { vdW + Hbond + } \\
\text { dissolve Energy }\end{array}$ & $\begin{array}{c}\text { Electrostatic } \\
\text { Energy }\end{array}$ & $\begin{array}{c}\text { Total Intermolec. } \\
\text { Energy }\end{array}$ & Frequency & $\begin{array}{c}\text { Interact. } \\
\text { Surface }\end{array}$ \\
\hline$-7.17 \mathrm{kcal} / \mathrm{mol}$ & $5.58 \mathrm{uM}$ & $-8.41 \mathrm{kcal} / \mathrm{mol}$ & $\begin{array}{c}-0.06 \\
\mathrm{kcal} / \mathrm{mol}\end{array}$ & $-8.48 \mathrm{kcal} / \mathrm{mol}$ & $50 \%$ & 674.252 \\
\hline
\end{tabular}


RASĀYAN J. Chem.

Vol. 12 | No. 2 |677 - 684| April - June | 2019

Table-2: Decomposed Interaction Energies in $\mathrm{Kcal} / \mathrm{mol}$

\begin{tabular}{c|c|c|c}
\hline Hydrogen Bonds & Polar & Hydrophobic & Other \\
\hline GLY142 (0) & ASP69 (0) & ILE171 (-0.1302) & THR179 (-0.259) \\
\hline & SER140 (0) & ALA12 (-0.0414) & ASN206 (0) \\
\hline & & ALA99 (0) & GLN11 (0) \\
\hline & & TYR224 (0) & GLN15 (0) \\
\hline & & & GLU183 (0) \\
\hline & & & GLU71 (0) \\
\hline
\end{tabular}

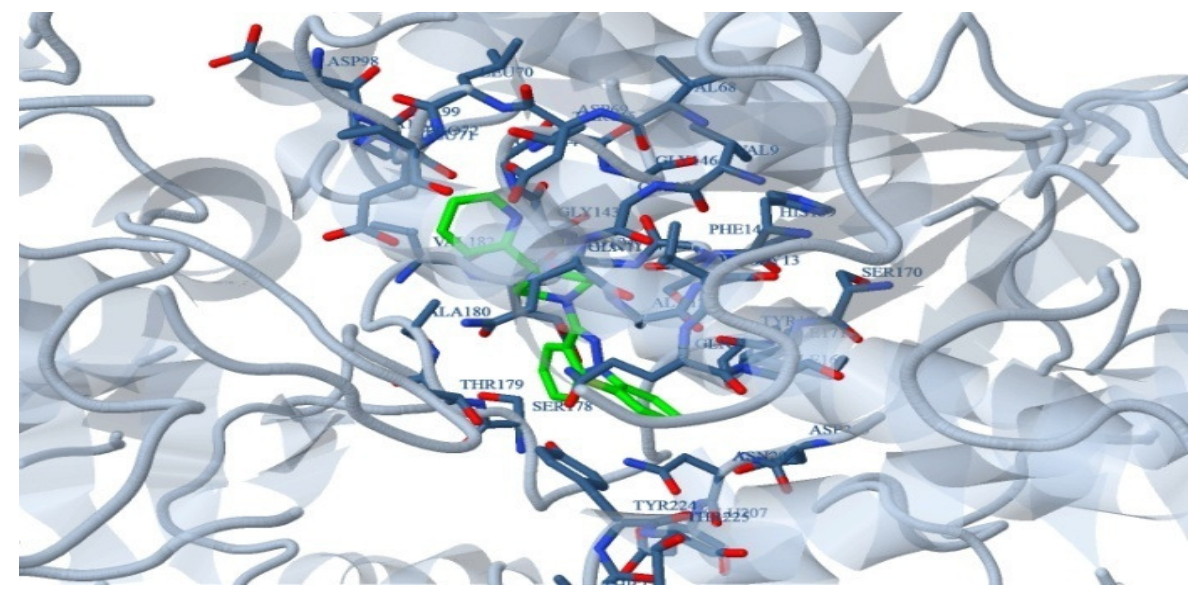

Fig.-2: Compound to 1jff - Structural Protein

Table-3: Interaction Table

\begin{tabular}{|c|c|c|c|c|}
\hline Hydrogen Bonds & Polar & Hydrophobic & pi-pi & Other \\
\hline \multirow[t]{7}{*}{$\begin{array}{l}\mathrm{N} 3() \\
{[3.42]}\end{array}-\begin{array}{c}\text { GLY14 } \\
2(O)\end{array}$} & $\begin{array}{l}\text { N5 () } \\
{[3.78]}\end{array}-\begin{array}{l}\text { ASP69 } \\
(\text { OD2 })\end{array}$ & $\begin{array}{c}\mathrm{C} 16() \\
{[3.36]}\end{array}-\begin{array}{c}\text { ALA12 } \\
(C B)\end{array}$ & $\begin{array}{cc} & \text { TYR22 } \\
& 4 \\
\text { C10 () } & -(C D 2, \\
{[3.57]} & C E 2 \\
& C Z) \\
& \end{array}$ & $\begin{array}{c}\mathrm{C} 18() \\
{[2.97]}\end{array}-\begin{array}{c}\text { GLN11 } \\
(C B)\end{array}$ \\
\hline & $\begin{array}{l}\text { N1 () } \\
{[3.76]}\end{array}-\begin{array}{l}\text { SER14 } \\
0(O G)\end{array}$ & $\begin{array}{l}\text { C8 () } \\
{[3.85]}\end{array}-\begin{array}{c}\text { ALA12 } \\
(C B)\end{array}$ & $\begin{array}{cc} & \text { TYR22 } \\
\text { C11 }() & 4 \\
{[3.69]-} & (C D 2, \\
& C E 2)\end{array}$ & $\begin{array}{c}\mathrm{C} 19() \\
{[3.14]-}\end{array}-\begin{array}{c}\text { GLN11 } \\
(C B)\end{array}$ \\
\hline & & $\begin{array}{l}\text { C9 }() \\
{[3.40]}\end{array}-\begin{array}{c}\text { ALA12 } \\
(C B)\end{array}$ & $\begin{array}{l}\text { C9 }() \\
\text { TYR22 } \\
{[3.58]-4(C E 1,} \\
C Z)\end{array}$ & $\begin{array}{c}\mathrm{C} 20() \\
{[3.35]}\end{array}-\begin{array}{c}\text { GLN11 } \\
(C B)\end{array}$ \\
\hline & & $\begin{array}{c}\text { C21() } \\
{[3.63]}\end{array}-\begin{array}{c}\text { ALA99 } \\
(C B)\end{array}$ & & $\begin{array}{l}\text { N1 () } \\
{[3.32]-{ }^{\text {ALA12 }}} \\
(C B)\end{array}$ \\
\hline & & 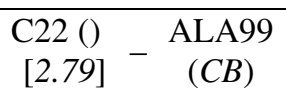 & & $\begin{array}{l}\text { F1 () } \\
{[3.22]}\end{array}-\begin{array}{c}\text { ALA12 } \\
(C B)\end{array}$ \\
\hline & & $\begin{array}{c}\text { C23() } \\
{[3.65]-\begin{array}{c}\text { ALA99 } \\
(C B)\end{array}}\end{array}$ & & $\begin{array}{l}\text { F1 () } \\
{[3.31]-\begin{array}{l}\text { GLN15 } \\
(N E 2)\end{array}}\end{array}$ \\
\hline & & $\begin{array}{cc}\mathrm{C} 12() & \text { ILE171 } \\
{[3.28]} & -\quad(C D 1, \\
& C G 2)\end{array}$ & & $\begin{array}{c}\text { C22() } \\
{[3.36]}\end{array}-\begin{array}{l}\text { ASP69 } \\
(\text { OD2) }\end{array}$ \\
\hline
\end{tabular}


RASĀYAN J. Chem.

Vol. 12 | No. 2 |677 - 684| April - June | 2019

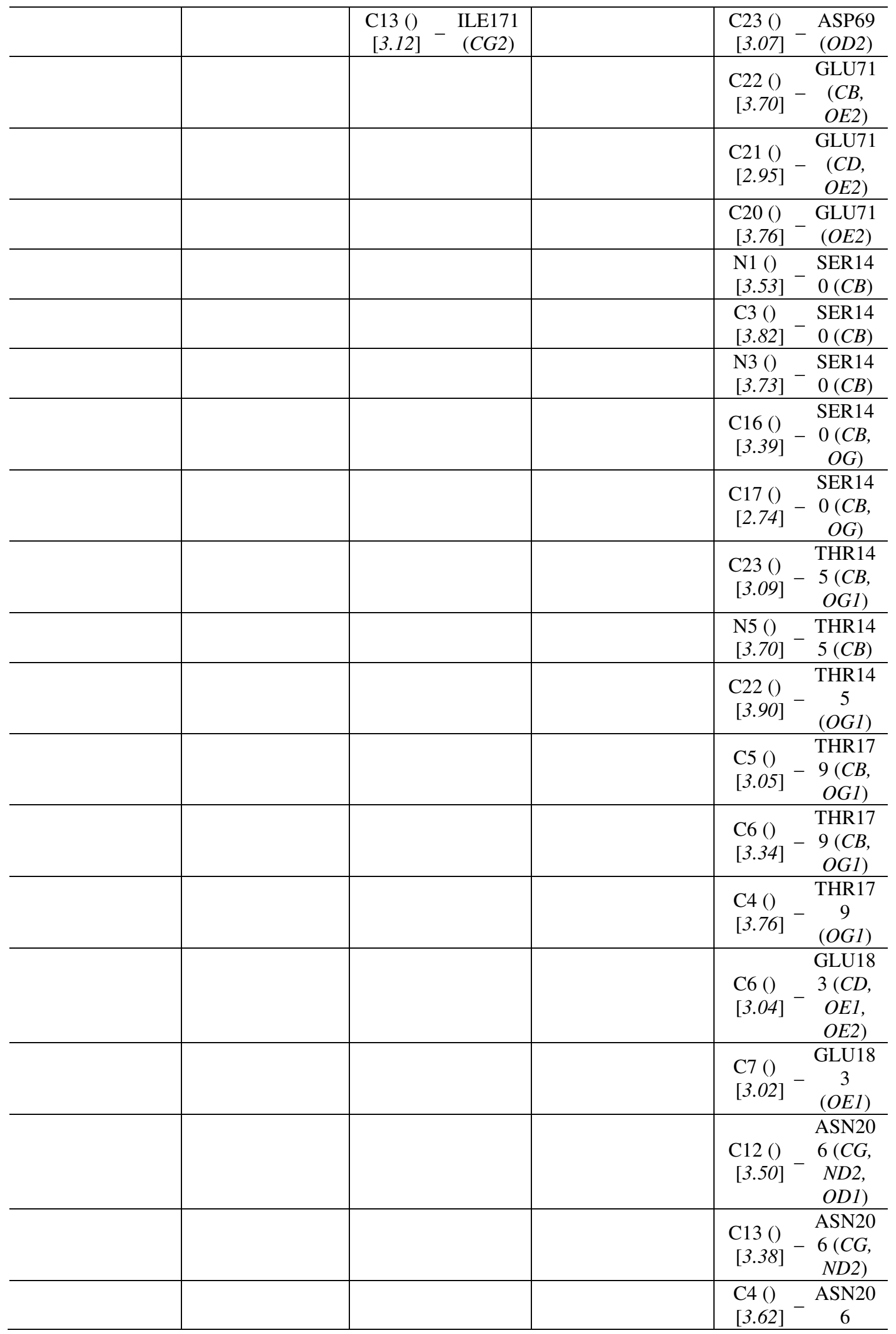


RASĀYAN J. Chem.

Vol. 12 | No. 2 |677 - 684| April - June | 2019

\begin{tabular}{l|l|l|l|l}
\hline & & & & (ND2) \\
\hline & & & & $\begin{array}{l}\text { F1 }()-\text { TYR22 } \\
{[3.60]-4(C E 1,} \\
C Z)\end{array}$ \\
\hline & & & & $\begin{array}{l}\text { C4 () TYR22 } \\
{[3.43]-4(O H)}\end{array}$ \\
\hline & & & & $\begin{array}{l}\text { C8 () TYR22 } \\
{[3.75]-4(O H)}\end{array}$ \\
\hline & & & & C9 () TYR22 \\
& & & & {$[3.73]-4(O H)$} \\
\hline
\end{tabular}

Table-4: Compound to 5cox - Oxidoreductase

\begin{tabular}{c|c|c|c|c|c|c}
\hline $\begin{array}{c}\text { Est. Free Energ } \\
\text { y of Binding }\end{array}$ & $\begin{array}{c}\text { Est. Inhibition } \\
\text { Constant, Ki }\end{array}$ & $\begin{array}{c}\text { vdW + Hbond + } \\
\text { dissolve Energy }\end{array}$ & $\begin{array}{c}\text { Electrostatic } \\
\text { Energy }\end{array}$ & $\begin{array}{c}\text { Total Intermole } \\
\text { c. Energy }\end{array}$ & $\begin{array}{c}\text { Freque } \\
\text { ncy }\end{array}$ & $\begin{array}{c}\text { Interact. } \\
\text { Surface }\end{array}$ \\
\hline$-4.31 \mathrm{kcal} / \mathrm{mol}$ & $695.36 \mathrm{uM}$ & $-5.34 \mathrm{kcal} / \mathrm{mol}$ & $-0.11 \mathrm{kcal} / \mathrm{mol}$ & $-5.46 \mathrm{kcal} / \mathrm{mol}$ & $50 \%$ & 557.587 \\
\hline
\end{tabular}

Table-5: Decomposed Interaction Energies in $\mathrm{kcal} / \mathrm{mol}$

\begin{tabular}{c|c|c|c}
\hline Hydrogen Bonds & Polar & Hydrophobic & Other \\
\hline SER38 (0) & ASN68 (0) & PRO35 (0) & GLU67 (0) \\
\hline & TYR55 (0) & PRO40 (0) & \\
\hline & & VAL165 (0) & \\
\hline
\end{tabular}

Table-6: Interaction Table

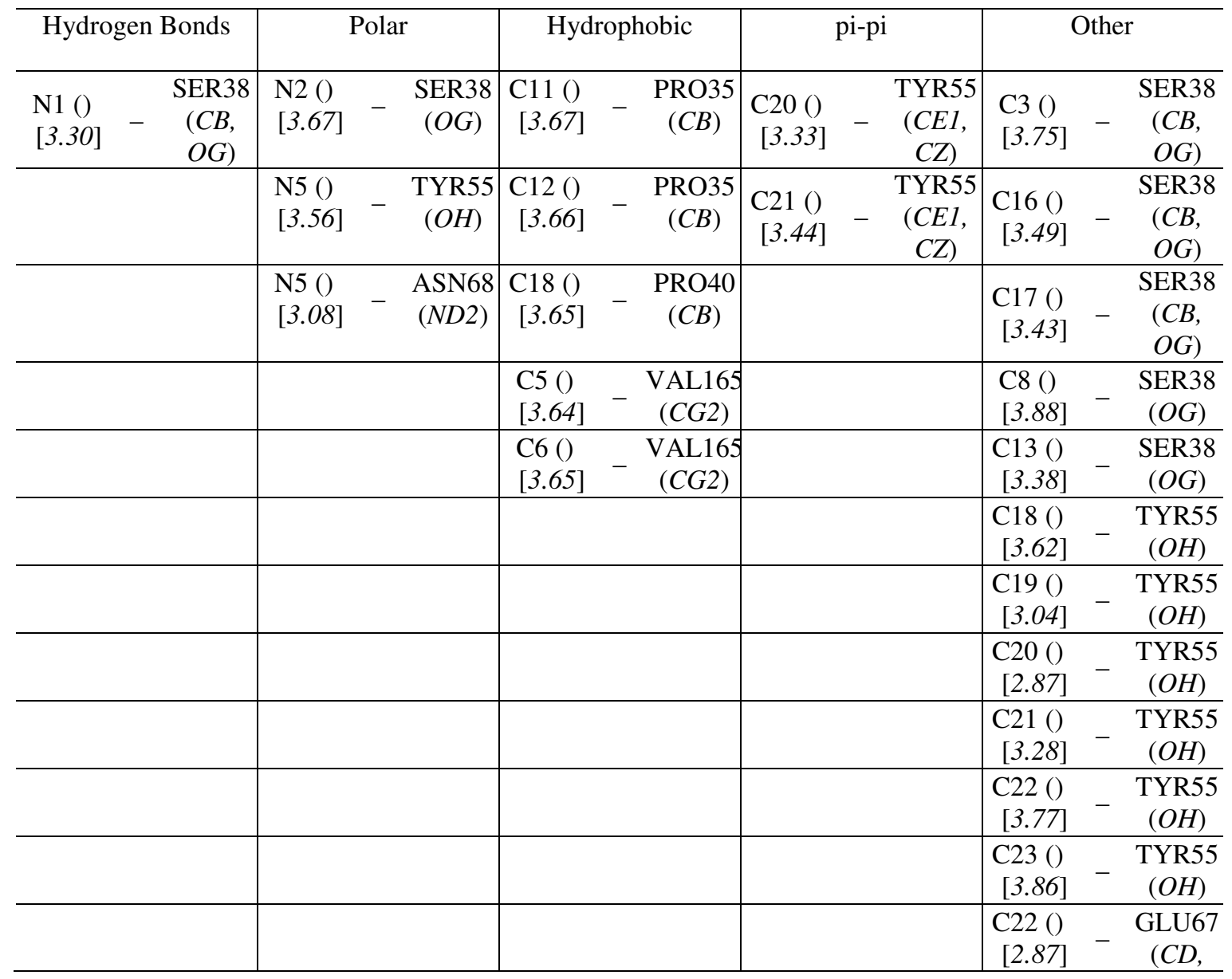


RASĀYAN J. Chem.

Vol. 12 | No. 2 |677 - 684| April - June | 2019

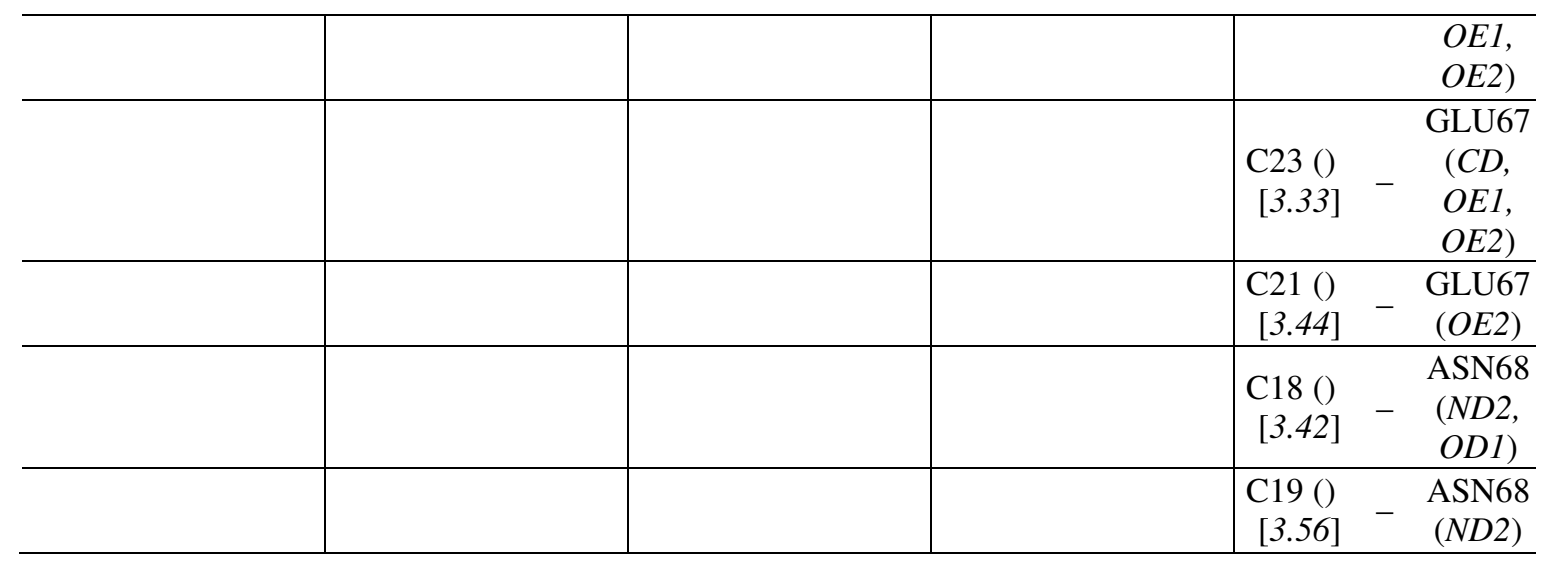

\section{REFERENCES}

1. N. Srinivasan, A. Balaji, G. Nagarajan, R. Suthakaran, Y. Kumar, D. Jagadesh, Asian J. Chem., 20, 4934 (2008)

2. V.G. Matassa, T. P. Jr. Maduskuie, H.S. Shapiro, B. Hesp, D.W. Snyder, D. Aharony, R.D. Krell, R.A. Keith, J. Med Chem., 33, 1781(1990)

3. D. R. James, L.J. Barry, Wang, Haisheng, A.G. Roger, E.V. Susan, M.K. Ronald, C.C. Beverly, M.R. Marlene, N.L. Gilbert, C.H. Chang, Bioorg. Med. Chem. Lett., 6, 2919 (1996)

4. J.A. Vicente, O. Carmen, Lucia, Boiani, Pablo, Buccino, Hugo, Cerecetto, Alejandra, Gerpe, Mercedes, Gonzalez, David, Montero, J.N. Juan, G.B. Alicia, Amava, Azqueta, L.D.C. Adela, E.P. Oscar, E.C. Eduardo, Bioorg. Med. Chem. 13, 3197 (2005)

5. K.W. Woods, A. Claiborne, Fischer, S.A. Thomas, G.D. Zhu, R.B. Diebold, X. Liu, Y. Shi, V. Klinghofer, T. Li, E.K. Han, R. Guan, S.R. Magnone, E.F. Johnson, J.J. Bouska, A.M. Olson, R.D. Jong, T. Oltersdorf, Y. Luo, S.H. Rosenberg, V.L. Giranda, Q. Li, Bioorg. Med. Chem., 14, 6832 (2006)

6. D.A. Meri, Fabio, Stossi, A.C Kathryn, S.K. Benita, A.K. John, J. Med. Chem.,48, 1132-1144 (2005)

7. K. T. Vishnu, B. Y. Dharmendra, K.C. Ashok, K. S. Praveen, Bioorg. Med. Chem. Lett, 15, 3288 (2005)

8. Letizia, Crocetti., Maria, P. G.Igor, A.S., Mark, T.Q., Andrei, I.K., Agostino, Cilibrizzi., Vittorio, D. P., Alessia, Graziano, C. Vergelli, Bioorganic \& Medicinal Chemistry., 19, 4460 (2011)

9. G. Surendrareddy, M. K. Arunasree, P. K. Dubey, A. Veerareddy, J. Chem. Sci., 126, 1055 (2014).

10. A. Veerareddy, G. Surendrareddy, P. K. Dubey, B. Madhavareddy, B. Veeresh, J. Chem. Sci.,127,433 (2015)

11. S. Plescia., D. Raffa, Fabiana, P. Giovanni, C. Benedetta, M. Giuseppe, D. Maria, V.R., Maria,G. C. Gabriella, B. Fiorella, ARKIVOC.,163, 1551(2010)

12. R. Sreenivasulu, P.Sujitha, S. J. Surender, A. Mohamedand, C. G. R. Rameshraju, Monatsheftefür Chemie - Chemical, 148, 305(2017), DOI: 10.1007/s00706-016-1750-6

13. P.V. Jaime, Y.M.Lilián, G.S. Ignacio, F.P.E Juan, S.A. Olivia, D.R.S.E. Teresita, A.C Marco, R.V Karen, R.V Anakrina, C.G. Miguel, C.G. Zeltzin, E.C. Dante, Molecules, 22, 1864 (2017)

14. G. Trivikramreddy, M. V. Venkatesh, R. B. Mohan, N.C. Gangireddy, iMedPub Journals, 4 (1), (2017)

15. Z. Bikadi, E. Hazai, J. Cheminf. 1, 15 (2009), DOI:10.1186/1758-2946-1-15

16. K. Srivani, T. Thirupathaiah, E. Laxminarayana, M. Thirumala Chary, Rasayan J. of Chem., 11(3), 1004 (2018), DOI: $10.31788 /$ RJC.2018.1134008

17. M. Siddhartha, E. Laxminarayana, G. Dayakar, Rasayan J. of Chem., 11(4), 1674 (2018), DOI: $10.31788 /$ RJC.2018.1144087

[RJC-5111/2018] 